\title{
FUZZY LOGIKÁT ALKALMAZÓ VONALKÖVETÕ AUTÓ VISELKEDÉSÉNEK VIZSGÁLATA
}

\author{
Könczöl Boldizsár ${ }^{a}$, Gál László ${ }^{b^{*}}$, \\ ${ }^{a}$ ELTE, Informatikai Kar, Savaria Múszaki Intézet, Programtervezố informatikus BSc, 3. évf. \\ ${ }^{b}$ ELTE, Informatikai Kar, Savaria Müszaki Intézet, egyetemi docens
}

\begin{abstract}
ABSZTRAKT
Fuzzy logikán alapuló vonalkövetô autót valósítottunk meg Arduino Uno és érzékelők felhasználásával. Ezen logikáknak különféle implementációs lehetôségei vannak, célunk megmutatni, hogy az általunk választott különböző t-normák mennyire használhatók a vonalkövetés során, van-e köztük mérhető különbség. A kiválasztott t-normák (standard, algebrai, drasztikus, Łukasiewicz, trigonometrikus, Hamacher szorzat) közül egy (a drasztikus t-norma) kivételével mindegyik megfelelően viselkedett, és megállapítottuk, hogy nagyon egyszerú szabályok alkalmazásával is jól megvalósítható a vonalkövetés.
\end{abstract}

Kulcsszavak: fuzzy, t-norma, Arduino, vonalkövetés

\section{Bevezetés}

Napjainkban egyre inkább fontos szerephez jutnak az önvezetô autókkal kapcsolatos kutatások. Ezen jármúveknek felhasználói beavatkozás nélkül kellene képesek lenniük az önálló navigációra, vezetésre. Ezek az autók többféle szenzorral és kamerákkal, különbözô algoritmusok szerint analizálják a közlekedési helyzeteket és hozzák meg a döntést úgy, hogy rengeteg bemenô jelet, információt számításba vesznek. A hagyományos Boole algebra, a kétértékú logika többek között az ilyen helyzetekre sem igazán megfelelő. Korábban többféle új módszert javasoltak, ami nem kétértékú, hanem többértékú logikát valósít meg. Ilyen a fuzzy logika is, amely pontosan arra hivatott, hogy több bemenő adat alapján adjon vissza egy értéket, vagy ezeket felhasználva küldjön jelet egy irányító kimenetre. Nincsenek benne szigorú (éles) szabályok, hanem egy fokozatosan, egymásba átnyúló szabályokból álló szabályrendszer alapján számolhatunk. A fuzzy logikát eleinte a nyugati országok nem tartották gyakorlati alkalmazásra hasznosnak, a keletiek, különösképpen a japánok viszont annál inkább. Előbb sikeresen szimulálták annak használatát a sendai vasúti közlekedésben, majd ezt meg is valósították 1987-ben [1]. A fuzzy logika mindennapi használata nem újkeletú dolog. Meglepô, de szinte mindenki használta már, amikor például nagyon hideg, hideg, kicsit hideg, kicsit meleg, meleg, nagyon meleg, forró szavakkal illetett bizonyos dolgokat. Egy programozható mikrovezérló alaplap (Arduino Uno) és a hozzá kapcsolt infravörös érzékelővel ellátott modulok segítségével terveztünk egy modellautót, amely képes a felhasználó által megrajzolt vonalat követni. A modellautó „döntéshozatalához” fuzzy logikát, fuzzy múveleteket (t-norma és t-konorma) és fuzzy irányítót implementáltunk. Ezek használatának egyik érdekessége, hogy különbözô t-norma párok alkalmazásával is megvalósíthatóak. A lefuttatott tesztek alapján összehasonlítjuk, hogy mely megoldások alkalmasabbak a felvázolt probléma megoldására.

(C) ELTE, Informatikai Kar, Savaria Műszaki Intézet, 2020

*Kapcsolattartó: gl@inf.elte.hu

https://doi.org/10.37775/EIS.2020.1.6 


\subsection{Fuzzy logika alapok}

A fuzzy halmazok alapfogalmaihoz nagy segítséget nyújt, ha a hagyományos halmazelmélet alapvetô fogalmait és azok tulajdonságait ismerjük. A halmazelméletek megkülönböztetésére a hagyományos, nem fuzzy halmazokra a crisp halmaz szókapcsolatot használjuk.

- Tagsági függvény: A fuzzy tagsági függvény egy leképezést valósít meg a vizsgált terület alaphalmazbeli (univerzumbeli) értékei és a [0,1] intervallum között [2]. Jel:

$$
\mathrm{A}: \mathrm{X} \longmapsto[0,1]
$$

- Fuzzy halmaz: A tagsági függvény által definiált halmaz.

- Tagsági érték: A tagsági függvény valamely crisp alaphalmaz minden eleméhez az értékkészletéből egy tagsági értéket rendel.

- Halmaz tartója: Valamely A fuzzy halmaznak 0-nál nagyobb tagsági értékû pontjainak összessége. Jel: $\operatorname{supp}(\mathrm{A})$.

- A halmaz magja: az alaphalmaz 1 tagsági értékkel rendelkezô pontjainak összességét értjük. Jel: $\operatorname{core}(\mathrm{A})$.

- A halmaz magasságán a tagsági függvényének legnagyobb értékét, azaz szuprémuma [3]. Jel:

$$
\mathrm{h}(\mathrm{A})=\sup _{x \in X} A(x) .
$$

\subsection{Müveletek fuzzy halmazokkal}

A hagyományos (crisp) halmazokon értelmezett három alapmúveletet (metszet, unió, negáció) a fuzzy halmazokon többféle módon lehet értelmezni. A Zadeh-féle (standard) értelmezés a legelterjedtebb a gyakorlati alkalmazásokban [3].

- Metszet: $(\mathrm{A} \cap \mathrm{B})(\mathrm{x})=\min [\mathrm{A}(\mathrm{x}), \mathrm{B}(\mathrm{x})]$.

- Unió: $(\mathrm{A} \cup \mathrm{B})(\mathrm{x})=\max [\mathrm{A}(\mathrm{x}), \mathrm{B}(\mathrm{x})]$.

- Negáció: $\overline{\mathrm{A}}(\mathrm{x})=1-\mathrm{A}(\mathrm{x})$.

Továbbá, ha x-re fennáll az $\mathrm{A}(\mathrm{x})=\overline{\mathrm{A}}(\mathrm{x})$ egyenlőség, akkor x az A halmaz egyensúlyi pontja. A metszet és unió múveletek asszociatívak, végtelen számú Fuzzy halmazra kiterjeszthetôk. Ezeket használjuk ki a projekt során is, mivel nekünk 3 adatot kell összevetnünk és azokra alkalmazni t-normákat, metszeteket.

\subsection{Alkalmazott t-normák}

A tesztek során az alábbi hat t-normát vizsgáltuk, az áttekinthetőség érdekében az ezekhez tartozó grafikonokat is ábrázoltuk (1-3. ábra).

1. Standard (minimum)

A minimum t-norma, a bemeneti értékek minimumaként értelmezi a metszet múveletet $i\left(\mu_{1}, \mu_{2}\right)$, ahol $\mu_{1}, \mu_{2}$ a szenzorok által mért értékek (1(a) ábra). Ekkor a kimenet $\left(w_{m}\right)$ :

$$
w_{m}=\min \left(\mu_{1}, \mu_{2}\right) \text {. }
$$

Három bemenet esetén:

$$
w_{m}=\min \left(\mu_{1}, \mu_{2}, \mu_{3}\right) .
$$




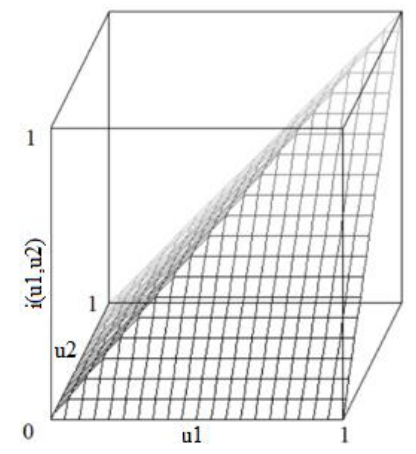

(a)

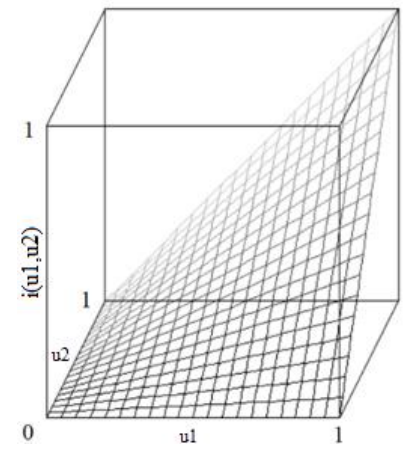

(b)

1. ábra: a) Standard (minimum) t-norma grafikonja [4], b) Algebrai t-norma grafikonja

2. Algebrai (szorzat)

Az algebrai t-norma a kalkulált értékek szorzatát adja kimeneti értékként (1(b) ábra):

$$
w_{a}=\mu_{1} \cdot \mu_{2} .
$$

Három bemenet esetén:

$$
w_{a}=\mu_{1} \cdot \mu_{2} \cdot \mu_{3} .
$$

\section{Drasztikus}

A szabály neve beszédes, ugyanis a kimeneti érték csak akkor nem 0 , ha valamelyik bemenet 1-es értékú, ezzel szinte mindenhol 0 a kimenet (2(a) ábra):

$$
w_{d}= \begin{cases}\mu_{1}, & \text { ha } \mu_{2}=1 \\ \mu_{2}, & \text { ha } \mu_{1}=1 \\ 0, & \text { minden más esetben. }\end{cases}
$$

Három bemenet esetén:

$$
w_{d}= \begin{cases}\mu_{1}, & \text { ha } \mu_{2}=1 \text { és } \mu_{3}=1 \\ \mu_{2}, & \text { ha } \mu_{1}=1 \text { és } \mu_{3}=1 \\ \mu_{3}, & \text { ha } \mu_{1}=1 \text { és } \mu_{2}=1 \\ 0 & \text { minden más esetben. }\end{cases}
$$

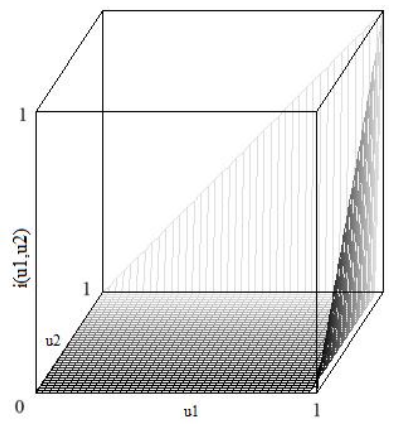

(a)

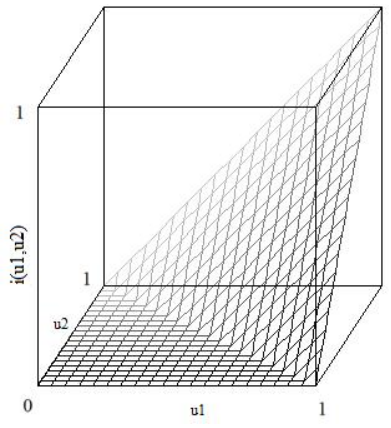

(b)

2. ábra: a) Drasztikus t-norma grafikonja, b) Łukasiewicz t-norma grafikonja 


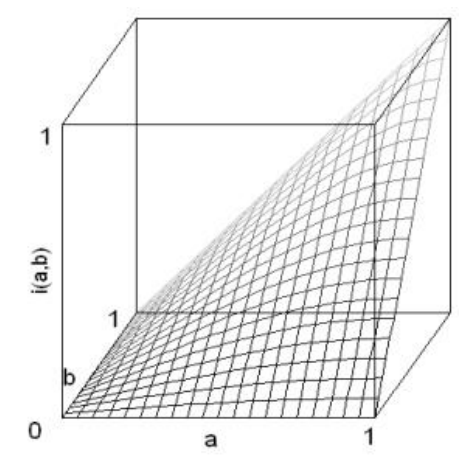

(a)

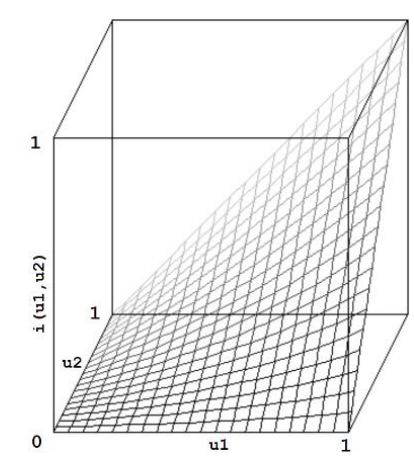

(b)

3. ábra: a) A trigonometrikus t-norma grafikonja, b) A Hamacher szorzat t-norma grafikonja

\section{Eukasiewicz}

Jan Łukasiewicz, lengyel matematikus háromértékú logikájának általánosított változata, a fuzzy logikában is használt t-norma (2(b) ábra).

$$
w_{\ell}=\max \left(0, \mu_{1}+\mu_{2}-1\right) .
$$

Három bemenet esetén:

$$
w_{E}=\max \left(0, \max \left(0, \mu_{1}+\mu_{2}-1\right)+\mu_{3}-1\right) .
$$

5. Trigonometrikus

Trigonometrikus függvényeken alapuló t-norma pár [5] (3(a) ábra):

$$
w_{t}=\frac{2}{\pi} \arcsin \left(\sin \left(\mu_{1} \frac{\pi}{2}\right) \cdot \sin \left(\mu_{2} \frac{\pi}{2}\right)\right) .
$$

Három bemenet esetén:

$$
w_{t}=\frac{2}{\pi} \arcsin \left(\sin \left(\mu_{1} \frac{\pi}{2}\right) \cdot \sin \left(\mu_{2} \frac{\pi}{2}\right) \cdot \sin \left(\mu_{3} \frac{\pi}{2}\right)\right) .
$$

\section{Hamacher}

A Hamacher paraméteres normapár $\nu=0$ paraméteres alapverziója (Hamacher szorzat, 3(b) áb$r a)$ :

$$
w_{H}=\frac{\mu_{1} \cdot \mu_{2}}{\mu_{1}+\mu_{2}-\mu_{1} \cdot \mu_{2}} .
$$

Három bemenet esetén:

$$
w_{H}=\frac{\mu_{1} \cdot \mu_{2} \cdot \mu_{3}}{\mu_{1} \cdot \mu_{2}+\mu_{1} \cdot \mu_{3}+\mu_{2} \cdot \mu_{3}-2 \cdot \mu_{1} \cdot \mu_{2} \cdot \mu_{3}} .
$$

\section{Hardver}

\subsection{A robot fố alkotórészei}

Arduino Uno (kompatibilis) alaplap Atmel ATmega328P mikrovezérlővel; Arduino Sensor Shield v5.0; L298N típusú H-hidas DC motorvezérlő; 4 db DC motor; HC-05 (ZS-040) bluetooth modul; a vonalkövetéshez 3 db MH-Sensor-Series infra érzékelő modul (LM393-as komparátorral); a tápellátásról 3 db sorba kötött 18650-es akkumulátorcella gondoskodott, melyet egy úgynevezett DC-DC „,step-down” modullal egészítettünk ki, így a feszültség mindvégig stabil $9 \mathrm{~V}$ marad (ez szükséges volt a konzisztens mérési eredmények érdekében). 


\subsection{Szükséges módosítások}

\section{Infra modulok}

Az elemek összekötése után soros monitorral ellenôriztük a bemeneti és kimeneti értékeket, mielőtt tényleges tesztekbe kezdtünk volna. Látványos különbségek voltak az infra érzékeló szenzorok értékei között a soros monitoron vizsgálva. Ennek oka, hogy e szenzorok esetén egy erôsebb és egy halványabb infravörös fényt kibocsátó modul is volt, melyek megállapítására egy mobiltelefon kameráját használtuk (az emberi szem számára láthatatlan infravörös fény a telefon kameráján keresztül kékes árnyalatú színben jelenik meg.) A szenzorokat és adatlapjaikat áttanulmányozva arra a következtetésre jutottunk, hogy a probléma a felületszerelt (SMD) $150 \Omega$-os ellenállás cserélésével orvosolható. A késóbbi problémák elkerülése végett nemcsak fix méretú ellenállást alkalmaztunk, hanem állíthatót, úgynevezett trimmert. A trimmerek elé mindkét esetben egy-egy 150 (-os ellenállást kapcsoltunk, hogy ha az állítható ellenállást 0 végállásba tekerjük, akkor se tegyük tönkre a szenzort, és a $150 \Omega$ legyen a legkisebb beállítható ellenállás.

\section{Tápellátás}

A tápellátásért eredetileg 4 db AA elem/akkumulátor felelt, de ezeknél a sebesség szabályozása elég limitált a 6/5,6 V feszültség miatt. Ez névleges feszültség, mivel amíg elér a motorokhoz addig különbözô szabályzókon és stabilizátorokon halad keresztül, amiknek köszönhetően körülbelül 4,5/4 V lesz a ténylegesen használható feszültség. Ezért inkább egy 3 db 18650-es akkumulátorból álló akkupakkot alkalmaztunk. Ez már 10,1-12,6 V feszültséget ad le a lítium alapú cellák töltöttségi fázisaitól függően, ami már jelentős sebességszabályozási lehetôségeket jelent. Ugyanakkor az akkupakk merüléséból származó folyamatos feszültségesés itt is befolyásolja a motorok viselkedését és szintén van veszteség, amíg a motorokhoz ér a feszültség. Ennél fogva, hogy a tesztek összehasonlíthatók legyenek, egy DC-DC step-down modullal stabil $9 \mathrm{~V}$ feszültséget állítottunk elô.

\section{Eredmények}

A teszteket egy fektetett fehér táblára felrajzolt, keresztezôdések nélküli pályán hajtottuk végre (4. ábra). A mérések során 3 kört kellett megtennie a modellautónak. A körbejárás idejét mindegyik teszt során „repülőrajtból” indulva mértük stopperrel. Minden esetben legalább 3 mérést végeztünk, ezek mediánjait hasonlítottuk össze. Az eredmények az 1. és 2. táblázatban láthatók. Mamdani típusú fuzzy irányítót implementáltunk COG defuzzyfikációs módszert alkalmazva. A fuzzy szabálybázis

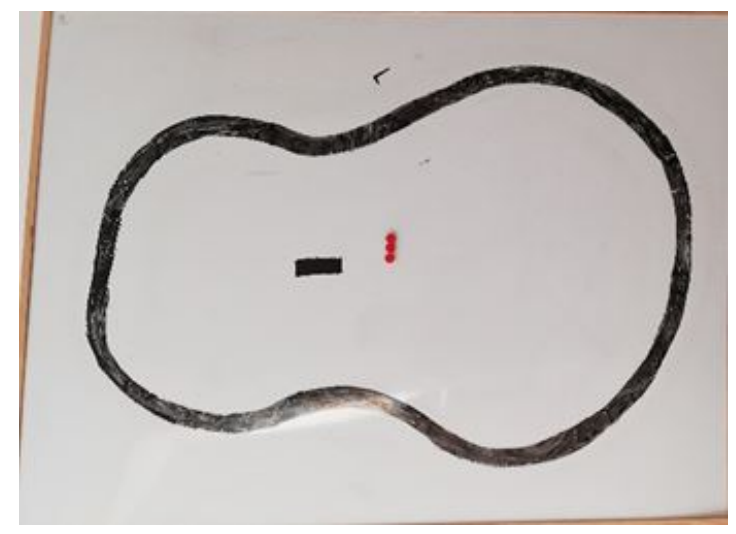

4. ábra: A pálya rajzolata 
1. táblázat: 1,92 sebességfaktorral mért idôk

\begin{tabular}{|l|c|} 
t-norma & idő [s] \\
\hline Minimum (4.) & 34,08 \\
Algebrai szorzat (2.) & 32,85 \\
Drasztikus & - \\
Eukasiewicz (1.) & 30,60 \\
Trigonometrikus (5.) & 34,45 \\
Hamacher (3.) & 33,57
\end{tabular}

2. táblázat: 2,5 sebességfaktorral mért idők

\begin{tabular}{|l|c|} 
t-norma & idő [s] \\
\hline Minimum (3.) & 26,68 \\
Algebrai szorzat (2.) & 25,58 \\
Drasztikus & - \\
Łukasiewicz (1.) & 25,50 \\
Trigonometrikus (5.) & 32,70 \\
Hamacher (4.) & 27,17
\end{tabular}

készítésénél kifejezetten nem törekedtünk optimális szabálybázis megalkotására. Azt szerettük volna tesztelni, hogy egy minimális elóismeretekkel rendelkezô ,szakértô” által gyorsan megkonstruált alap fuzzy szabálybázis múködését befolyásolja-e (és mennyiben) a különbözố t-normák alkalmazása.

A szabályok az alábbi formában kerültek kialakításra: Ha a bal érzékelő VILÁGOS, a középső érzékelő VILÁGOS és a jobb érzékelő VILÁGOS felületet érzékel, akkor a bal motor ÁLL. Ez röviden: R1: Ha $\{\mathrm{V}, \mathrm{V}, \mathrm{V}\}$, akkor ÁLL. Ez alapján a bal motorra vonatkozó szabályok (V=világos és $\mathrm{S}=$ sötét):

R1: Ha $\{\mathrm{V}, \mathrm{V}, \mathrm{V}\}$, akkor ÁLL.

R2: Ha $\{\mathrm{V}, \mathrm{V}, \mathrm{S}\}$, akkor ELŐRE_MAX.

R3: Ha $\{\mathrm{V}, \mathrm{S}, \mathrm{S}\}$, akkor ELÖRE.

R4: Ha $\{\mathrm{V}, \mathrm{S}, \mathrm{V}\}$, akkor ELŐRE.

R5: Ha $\{\mathrm{S}, \mathrm{S}, \mathrm{V}\}$, akkor HÁTRA.

R6: Ha $\{\mathrm{S}, \mathrm{V}, \mathrm{V}\}$, akkor HÁTRA_MAX.

R7: Ha $\{\mathrm{S}, \mathrm{S}, \mathrm{S}\}$, akkor ELŐRE_LASSÚ.

A jobb motorra vonatkozó szabályok értelemszerúen hasonlóak a bal és jobb érzékelő felcserélésének megfelelően. A V (világos) és S (sötét) trapéz alakú fuzzy tagsági függvényeket (antecedenseket) az alábbi értékekkel határoztuk meg (az érzékelóból 0-1023 tartományban kapunk adatokat, a nagyobb
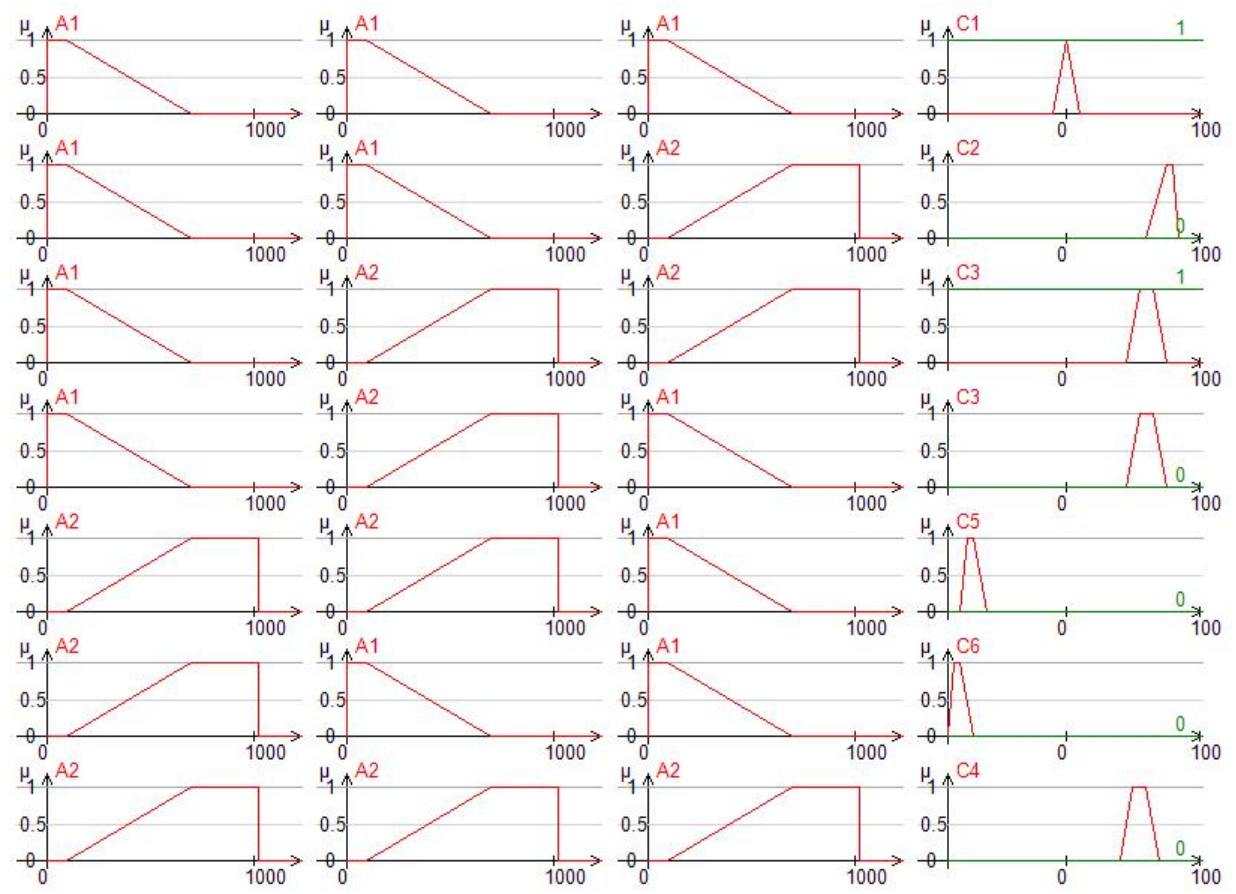

5. ábra: Baloldali motor szabálybázis 
érték a sötétebb, a 4 érték a trapéz 4 töréspontja):

$$
\begin{aligned}
& \mathrm{V}=\{-1,0,100,700\}, \\
& \mathrm{S}=\{100,700,1024,1025\} .
\end{aligned}
$$

A konklúziókban használt nyelvi elemekhez tartozó trapéz alakú fuzzy tagsági függvényeket eredetileg a következóképpen határoztuk meg (0-255-ös tartomány, a nagyobb érték gyorsabb motorforgatást eredményez):

$$
\begin{aligned}
& \text { ÁLL }=\{-10,0,0,10\}, \\
& \text { ELÖRE_MAX }=\{60,75,80,85\}, \\
& \text { ELŐRE }\{45,55,65,75\}, \\
& \text { ELŐRE_LASSÜ }=\{40,50,60,70\}, \\
& \text { HÁTRA_ }=\{-80,-75,-70,-60\}, \\
& \text { HÁTRA_MAX }=\{-90,-85,-80,-70\} .
\end{aligned}
$$

A baloldali motorhoz tartozó fuzzy szabálybázis vizuális reprezentációja a 5. ábrán látható. A megalkotott szabálybázis konklúzióit (a motorra kerülő feszültség kitöltési tényezôje; 0-255) egy adott feszültségre méreteztük. Azonban a 12 V-ra méretezett 55-ös értékkel lassan induló motor, ugyanezzel az 55-ös értékkel $6 \mathrm{~V}$ esetén el sem indulna. Annak érdekében, hogy az esetlegesen megváltoztatott (pl. $9 \mathrm{~V}$ ) tápfeszültség esetén ne kelljen új szabálybázist alkotni, a konklúziókban megadott értékeket egy általunk ,sebességfaktornak” elnevezett szorzóval állítottuk be a tényleges tápfeszültség esetén alkalmazandó értékekre.

Az elsố mérések során a sebességfaktort 1,92-os értékre állítottuk be. Ezt a sebességfaktort az elôzetes tesztek során állapítottuk meg, amely a 9 V-os tápfeszültség esetén megfelelő értékekre módosította a konklúziókat. Ez egy olyan érték, amellyel a drasztikus kivételével mindegyik használt norma képes volt végigmenni megállás nélkül a pályán. Az eredményeket az 1. táblázat tartalmazza. További méréseket végeztük 2,5-es sebességfaktorral is, hogy lássuk a sebesség ilyen módon való emelése nincs-e lényeges hatással a különböző normák összehasonlítására (2. táblázat).

\section{Következtetések}

A mérési eredményekból látható, hogy a drasztikus kivételével mindegyik általunk vizsgált t-norma (standard, algebrai, Łukasiewicz, trigonometrikus, Hamacher szorzat) alkalmas a vonalkövetés megvalósítására. Az elsố mérések során kialakult egy sorrend, amely alapján gyorsaság szempontjából rangsoroltuk a normákat. A második, nagyobb sebességfaktor melletti mérések nem befolyásolták jelentôsen a már kialakult sorrendet. Csupán a standard és a Hamacher t-norma cseréltek helyet (valószínúleg a mérési hibahatáron belüli különbségekkel). Fontos tudni, hogy a végzett mérésekból csak arra következtethetünk, hogy a normák használhatók-e, és ha igen, akkor milyen sebességgel tudnak végig menni a tesztpályán. Azt, hogy mennyire tér le a pályáról, mennyire követi a vonalat, azt jelen körülmények között nem vizsgáltuk. További fontos megjegyzés, hogy az Arduino Uno kor-

3. táblázat: $2 \cdot 1024$ következtetés időigénye Arduino Uno esetén

\begin{tabular}{|l|c|} 
t-norma & idő [ms] \\
\hline Minimum & 3704 \\
Algebrai szorzat & 3758 \\
Drasztikus & 3756 \\
Eukasiewicz & 4035 \\
Trigonometrikus & 11665 \\
Hamacher & 4448
\end{tabular}


látos teljesítménye miatt a fuzzy számítások lefutása között is időbeli eltérések vannak. A 3. táblázat a különböző normák szerinti $2 \cdot 1024$ következtetés számítási idejét tartalmazza.

A trigonometrikus norma jól láthatóan nagyobb számítási igényú a tesztek során használt hardveren. Ennek elsődleges oka a lebegópontos egység hiánya az adott mikrovezérlônél, valamint a viszonylag alacsony órajel. Egy erôsebb központi feldolgozó egységgel ellátott eszközzel (például NodeMCU (ESP32)) a feldolgozás sokkal gyorsabb lenne. Ez esetben a megfelelő normák más eredményeket adhatnak.

Habár a trigonometrikus norma használatával a vonalkövetés a leglassabbnak bizonyult (bár nem igazán jelentôs az eltérés), úgy gondoljuk, hogy a gyengébb teljesítmény mögött valószínúleg a hosszabb számítási idő miatti lassabb reakcióidô áll. A ritkább iránykorrekció lehetôsége nyilvánvalóan rontja az eredményt. Még ha a következtetési idók arányaiban hasonlóak maradnának is, egy gyorsabb hardveren ennek jelentősége jelentősen csökkenne. A következtetés ideje a ms-os időtartományból a us-os tartományba mozogna, míg az elóbbi számottevően (hátrányosan) befolyásolja a jármú mozgását, az utóbbi nem. A közeljövőben a fenti modullal is szeretnénk a méréseket elvégezni.

\section{Köszönetnyilvánítás}

A cikk az EFOP-3.6.1-16-2016-0023 támogatásával készült.

\section{Irodalomjegyzék}

[1] Oláh F., A Fuzzy Logika - Alapismeretek, Autótechnika 05, 2009, pp. 42-43

[2] Johanyák Zs.Cs., Kovács Sz., A fuzzy tagsági függvény megválasztásáról, in A GAMF Közleményei, Kecskemét, 2004 (XIX. évfolyam), 1. oldal

[3] Kóczy L.T., Tikk D., Fuzzy rendszerek, Tyoptex Kiadó, 2001.

[4] Gál L., Fuzzy modellek optimalizálása bakteriális típusú algoritmusokkal, doktori disszertáció, Széchenyi István Egyetem, Gyôr, 2012.

[5] Gál L., Lovassy R., Kóczy L.T., Function Approximation Performance of Fuzzy Neural Networks Based on Frequently Used Fuzzy Operations and a Pair of New Trigonometric Norms, 2010 IEEE World Congress on Computational Intelligence, WCCI-2010, Barcelona, Spain, July 18-23, 2010, pp. 1514-1521 CrossRef 